\title{
Spatial Variation in the Distribution and Abundance of Submersed Macrophytes in
} an Australian Subtropical River

Stephen J. Mackay ${ }^{1,3}$, Angela H. Arthington ${ }^{1,2}$, Mark J. Kennard ${ }^{1}$ and Bradley J. Pusey ${ }^{2}$

${ }^{1}$ Cooperative Research Centre for Freshwater Ecology, Centre for Catchment and InStream Research, Faculty of Environmental Sciences, Griffith University, Kessels Road, Nathan, 4111, Queensland, Australia.

${ }^{2}$ Cooperative Research Centre for Tropical Rainforest Ecology and Management, Centre for Catchment and In-Stream Research, Faculty of Environmental Sciences, Griffith University, Kessels Road, Nathan, 4111, Queensland, Australia.

3 To whom correspondence should be sent. Address for correspondence: Centre for Catchment and In-Stream Research, Griffith University, Kessels Road Nathan 4111 Queensland, Australia.

Tel: +61 73875 7101, Fax +61 73875 7615. E-mail: s.mackay@mailbox.gu.edu.au

\section{Abstract}

Spatial variation in the distribution and abundance of submersed macrophytes in the Mary River, a subtropical Australian river, was examined at 29 sites on four occasions (116 samples) over a one year period. Thirteen submersed macrophyte taxa representing seven families were recorded during the study period. Submersed macrophyte cover was generally patchy and mean quadrat cover per sample was below 7\% for every recorded taxon. Classification and ordination identified four distinct groups characterised by differences in submersed macrophyte abundance and associated environmental variables. 
Three of the four groups were characterised by different abundances of three core taxa, Myriophyllum verrucosum, Vallisneria nana and Potamogeton crispus. The distribution of the four sample groups within the Mary River catchment was associated with two environmental gradients, the first gradient representing discharge intensity, discharge variability and total Kjeldahl nitrogen concentration and the second gradient representing discharge intensity, substrate composition, riparian canopy cover and total phosphorus concentration. Both environmental gradients were constrained by geomorphology at the catchment as well as the reach scale. Our findings are consistent with a general conceptual model that highlights the importance of major environmental gradients in structuring submersed macrophyte assemblages.

Keywords: Submersed macrophytes; distribution; abundance; spatial variation; environmental gradients; conceptual model

\section{Introduction}

Anthropogenic disturbance of riverine ecosystems has been cited as an important cause of degradation to lotic macrophyte assemblages, with responses including excessive macrophyte growth, loss of native species and invasion by exotic species (e.g. Litav and Agami, 1977; Schütz, 1995; French and Chambers, 1997; Bunn et al., 1998; Demars and Harper, 1998; King and Buckney, 2000). Conceptual and predictive models are seen as essential management tools for understanding and minimising anthropogenic impacts upon aquatic macrophyte assemblages, and ensuring the conservation of rare or endangered macrophyte taxa (e.g. Keddy, 1992; Carr et al., 1997; Hill et al., 1998). Development of predictive models requires an understanding of the relationships between aquatic 
macrophyte assemblage structure and environmental parameters in undisturbed catchments (e.g. Hart and Finelli, 1999). The environmental parameters that control the distribution and abundance of aquatic macrophytes in unregulated Australian streams and rivers have received little attention compared to the effort focussed on lake and wetland macrophyte assemblages (e.g. Brock, 1991; Royle and King, 1991; Casanova, 1994; Rea and Ganf, 1994), thereby hindering the development of predictive models and appropriate management strategies for aquatic macrophytes in lotic systems.

Recent studies in Europe and elsewhere have emphasised the influence of multiple interacting environmental factors on the distribution and abundance of lotic macrophytes (Muotka and Virtanen, 1995; Biggs, 1996; Suren, 1996; Carr et al., 1997; Suren and Ormerod, 1998; Carr and Chambers, 1998; Riis et al., 2000). The relative importance of environmental factors to macrophyte assemblage structure has been shown to vary spatially and temporally (Sand-Jensen et al., 1989; Biggs, 1996; Suren, 1996; Suren and Ormerod, 1998) and over different scales of habitat resolution (Farmer and Adams, 1989; Hughes, 1990; Chambers et al., 1991; French and Chambers, 1996; Palmer and Poff, 1997). Consequently, it has been recommended that in situ studies of macrophytes in streams should simultaneously measure a suite of physical and chemical environmental variables to adequately characterise the abiotic environment of aquatic macrophytes (see Mitchell and Rogers, 1985; Farmer and Adams, 1989; Carr and Chambers, 1998).

In this paper we examine spatial variation in the composition of submersed macrophyte assemblages of the Mary River, a coastal river of southeast Queensland, Australia. Our objective is to relate spatial variation in the distribution and abundance of submersed macrophytes to environmental variables (catchment characteristics, discharge, water velocity, substrate composition, riparian cover and water quality). From these relationships we assess the applicability of a general conceptual model (Riis and Biggs 
2001) that highlights the importance of major environmental gradients in structuring submersed macrophyte assemblages.

\section{Methods}

\subsection{Study area}

The Mary River catchment, with an area of $9700 \mathrm{~km}^{2}$ and approximate main channel length of $300 \mathrm{~km}$ (Bridges et al., 1990; Johnson, 1997), is one of the larger river systems of subtropical southeast Queensland, Australia (Fig. 1). The Mary River conforms to the general pattern of high hydrologic variability and low annual runoff noted for Australian rivers in comparison to northern hemisphere rivers (Finlayson and MacMahon, 1988; Puckridge et al., 1998). The mean annual runoff of the Mary River catchment is approximately $2.3 \times 10^{9} \mathrm{~m}^{3}$ (Department of Primary Industries, 1993), much of which is supplied by tributaries draining the western part of the catchment (Pusey et al., 1993 and Fig. 1). Discharge is generally seasonal with summer maxima and winter-spring minima (Fig. 2). Tributaries (e.g. Amamoor Ck, Fig. 2) and upper reaches of the main channel may cease to flow during periods of low rainfall. The seasonal discharge pattern is to some extent obscured by the activity of tropical and temperate weather patterns that may produce winter spates (Fig. 2).

\subsection{Sites}

Sites were located where possible in tributary and river reaches considered to be relatively free of anthropogenic disturbance with respect to riparian habitat, water quality 
(particularly nutrients, turbidity) and flow regulation. All major tributaries and representative main channel habitats within the freshwater reaches were included in the study in order to encompass as much natural environmental variation in the catchment as possible. Twenty-nine sites were surveyed on fourth to seventh order streams, at elevations of up to 160 m Australian Height Datum (AHD; Fig. 1). Only one site (site 30, Yabba Creek) was directly influenced by flow regulation (Borumba Dam, total capacity $4.6 \times 10^{7}$ $\mathrm{m}^{3}$; SunWater, 2001). Each site was a distinct hydraulic unit (i.e. riffle, run or pool) between 20 and $60 \mathrm{~m}$ in length. In general, several sites were surveyed per stream reach (Fig. 1). Each site was surveyed on four separate occasions (May 1996, September 1996, January 1997, May 1997). This provided a total of 116 samples (i.e. 29 sites surveyed four times) describing submersed macrophyte composition and abundance and environmental parameters throughout the catchment.

\subsection{Sampling methods}

Submersed macrophyte abundance and environmental variables were quantified within $1 \mathrm{~m}^{2}$ quadrats according to a standard survey protocol. Quadrat position within each site was determined from random number pairs representing quadrat position within the stream in terms of distance upstream (from a fixed point) and position on a transect placed perpendicular to the direction of flow. In general 20-30 quadrats were surveyed per site sample. Submersed macrophyte abundance (as percentage cover of individual taxa per quadrat) was estimated as the proportion of space, within a vertical projection of the quadrat to the water surface, occupied by plant material (Ward and Talbot, 1984). Water velocity within each quadrat was recorded at 0.6 times the stream depth with a Swoffer model 2100 flow meter. Water depth was recorded to the nearest centimetre. Substrate 
composition was visually estimated using a modified Wentworth Scale as the proportion to the nearest $10 \%$ of mud $(<0.063 \mathrm{~mm}$ diameter), sand $(0.063-2 \mathrm{~mm})$, fine gravel $(2-16 \mathrm{~mm})$, gravel $(16-64 \mathrm{~mm})$, cobble $(64-128 \mathrm{~mm})$, rock $(128-512 \mathrm{~mm})$ or bedrock $(>512 \mathrm{~mm})$ present per quadrat. Water slope over the site length was measured with a staff and Sokkia automatic level. Riparian canopy cover directly above each quadrat was measured using a spherical densiometer (Lemmon, 1956). Water quality data (DO, $\mathrm{pH}$, conductivity, water temperature) for each quadrat were recorded in situ (Greenspan water quality sensors and Pacific Data Systems DT50 data logger). Turbidity was recorded at three locations within each site using a Hach model 16800 turbidimeter.

One water sample was collected from within each stream reach surveyed on each of the four sampling occasions for determination of major ions and nutrients (as total Kjeldahl nitrogen, TKN and total phosphorus, TP). One water sample per reach was considered sufficient as previous water quality sampling within the catchment has shown only minor differences in water quality between adjacent sites in the same reach (Mackay, Kennard and Arthington, unpublished). Water samples for major ion analysis were collected in $1 \mathrm{~L}$ detergent-washed polyethylene bottles and nutrient samples in $250 \mathrm{~mL}$ polyethylene bottles washed with reverse-osmosis purified water. Nutrient samples were frozen after collection (Queensland Department of Environment and Heritage, 1995) and analysed within five days of collection. All samples were analysed by the Queensland Government Chemical Laboratories using standard methods (American Public Health Association, 1995).

Catchment characteristics of individual sites (upstream catchment area, distance to river mouth, and elevation) were determined from Australia 1:100 000 topographic series maps. Submersed macrophytes were identified using keys (Stanley and Ross, 1983, 1986, 
1989; Sainty and Jacobs, 1994; Jacobs and Frank, 1997) or by comparison with reference material verified by the Queensland Herbarium.

\subsection{Statistical analysis}

Discharge statistics for individual Mary River sites were calculated from modelled discharge data (expressed as total daily discharge, TDD, $\mathrm{m}^{3} \mathrm{~d}^{-1}$ ) provided by the former Queensland Department of Natural Resources for the period 1994-1997. Defining discharge descriptors of most relevance to submersed macrophytes is not straightforward since very few studies have related specific discharge statistics to the distribution and abundance of submersed macrophytes. From the modelled data available we calculated seven discharge descriptors that were considered potentially relevant to submersed macrophytes and can be calculated easily without specialist software (Orchard, 1985; Poff and Ward, 1989; Biggs, 1996; Brock and Casanova, 1997). These variables were maximum and minimum total daily discharge, $10^{\text {th }}$ and $90^{\text {th }}$ percentiles of the total daily discharge, median total daily discharge, coefficient of variation (CV) of total daily discharge and number of zero flow days. Because of the limited temporal discharge data available (three years prior to sampling) we did not calculate flood frequencies, which may influence the structure of lotic communities (Poff and Ward, 1989). All discharge statistics were calculated from total daily discharge data for a time period defined by the 1095 days (365 days per year by 3 years) prior to the day of sampling, providing a short-term characterisation of the history of discharge events influencing submersed macrophytes and their habitat.

Spatial variation in submersed macrophyte species composition/abundance and relationships with environmental variables were examined by classification and ordination of samples using PATN (Belbin, 1995). All samples from each of the four surveys were 
analysed concurrently. As rare taxa may obscure patterns produced by classification and ordination those species occurring in less than $5 \%$ of samples were omitted from multivariate analyses (Gauch, 1982; Clarke and Warwick, 1994). Removal of rare taxa did not reduce the number of samples available for multivariate analysis. Submersed macrophyte cover estimates (as mean quadrat cover per sample, calculated from all of the quadrat estimates taken for that sample including quadrats without macrophytes) were $\log (\underline{x}+1)$ transformed prior to analysis. A sample by sample association matrix was generated using the Bray-Curtis dissimilarity measure and used to generate an agglomerative hierarchical classification (Unweighted Pair-Group Method Using Arithmetic Averages, UPGMA) with $\beta=-1$ (Belbin, 1995). An appropriate number of sample groups was determined by inspection of the dendrogram structure and use of the Group Definition (GDEF) function in PATN (Belbin, 1995). Kruskal-Wallis tests were used to compare means for species cover and environmental variables between sample groups identified by UPGMA (Zar, 1996).

Sample groups identified by UPGMA classification were confirmed by ordination of the sample by sample association matrix using Semi-Strong-Hybrid Multidimensional Scaling (SSHMDS; Belbin, 1995). Where possible, ordination stress was held below 0.15 (Belbin, 1995) by manipulating the number of dimensions and changing cut levels and regression techniques used. Each ordination was rotated to simple structure (Varimax rotation) to simplify interpretation. Species cover and environmental variables were correlated with the ordination space by Principal Axis Correlation, which uses multiple regression to fit attributes to an ordination space as vectors of best fit (Belbin, 1995). The significance of correlation coefficients produced by Principal Axis Correlation was tested using a Monte-Carlo procedure (Monte-Carlo Attributes and Ordination procedure in PATN) and 100 randomisations (Belbin, 1995). 


\section{Results}

\subsection{Spatial variation in environmental variables}

Pronounced spatial variation in environmental conditions occurred within the Mary River catchment (Table 1). Macroscale variables describing site position in catchment (upstream catchment area, distance to river mouth, elevation) were highly correlated with mesoscale and microscale variables describing physical (in-stream) habitat, discharge and water quality (Table 1). Water quality parameters were positively correlated with upstream catchment area and negatively correlated with site elevation (Table 1). Conductivity, $\mathrm{pH}$, alkalinity, nutrient concentrations and turbidity increased as catchment area increased and site elevation decreased. Similarly, water velocity and measures of discharge magnitude (i.e. maximum and minimum daily discharge, percentile measures) increased as catchment area increased and elevation decreased. Furthermore, the CV of total daily discharge was positively correlated with elevation and distance to mouth, indicating higher elevation sites were subjected to “flashier” stream discharges than lower catchment sites (see also Fig. 2).

\subsection{Submersed macrophyte assemblages}

Thirteen submersed macrophyte taxa were recorded from 25 of 29 sites (77 of 116 samples) surveyed in the Mary River catchment (Table 2). Submersed macrophytes were not recorded from Kilcoy Creek (sites 1-3) and Tinana Creek (site 46) on any of the four sampling occasions (16 samples in total), and sites in Wide Bay Creek (sites 38 and 39) 
were dry for the last two surveys in January and May 1997 (4 samples in total). Thirteen sites had submersed macrophytes present on each of the four sampling occasions.

Submersed macrophyte cover was generally patchy and mean cover per quadrat across all samples was below $7 \%$ for every taxon recorded (Table 2). However, extensive submersed macrophyte beds were present in Amamoor Creek (site 52), Booloumba Creek (site 6), Yabba Creek (site 30) and Wide Bay Creek (sites 38 and 39) where maximum cover values for some quadrats exceeded 50\% (Table 2). Submersed macrophyte assemblages were dominated by Myriophyllum verrucosum, Vallisneria nana and Potamogeton crispus (Table 2), occurring in 34\%, 30\% and 30\% of samples respectively.

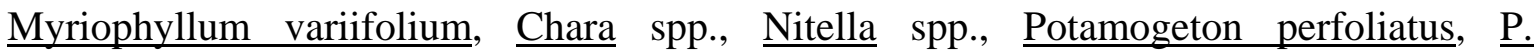

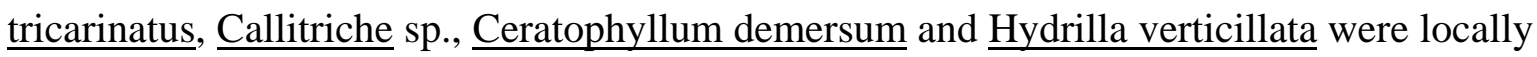
dominant taxa. Najas tenuifolia and $\underline{\text { P. ochreatus }}$ were rarely collected.

\subsection{Sample classification and relationships with environmental variables}

Nine common taxa (i.e. taxa occurring in more than $5 \%$ of samples, Table 2) were used in the classification of Mary River samples. UPGMA sample classification produced four clearly defined sample groups with the mean cover per quadrat of seven taxa found to be significantly different between groups (Table 3). Each group was characterised by taxa clearly dominant in terms of percentage cover and/or frequency of occurrence (Table 3). Group 1 samples were dominated by $\underline{\mathrm{M}}$. variifolium and itella spp., with $\underline{\mathrm{M}}$. verrucosum

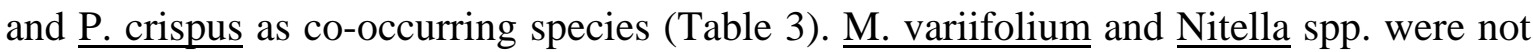
exclusive to group 1 but occurred rarely outside of it. Group 2 samples were clearly dominated by $\underline{\mathrm{V} \text {. nana. }}$. This species was often found in monospecific stands (41\% of group

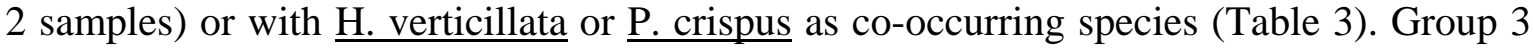




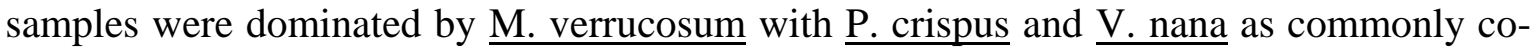

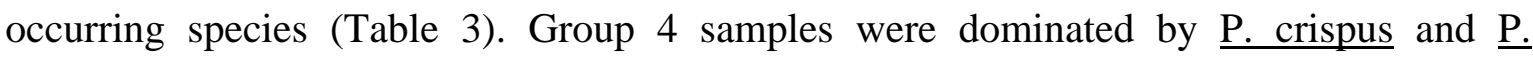
perfoliatus. These species were common within group 4 samples (93\% and $40 \%$ of group 4 samples respectively) but were not abundant, as shown by estimates of mean cover (Table

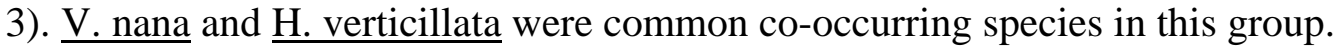

Each of the four sample groups identified by UPGMA classification was associated with particular environmental conditions (Table 4). Group 1 samples (․ variifoliumNitella spp.) were restricted to Amamoor Creek (sites 33, 52) and Booloumba Creek (sites $6,7)$ at elevations $\geq 100 \mathrm{~m}$ AHD. These samples were collected from pools with relatively coarse substrata, discharges of relatively low magnitude and low variability relative to other parts of the catchment, and frequent periods of zero discharge (Table 4; Fig. 2). Group 1 samples were associated with low TKN and TP concentrations (Table 4). Group 2 samples $(\underline{\mathrm{V} \text {. nana) }})$ were collected from sites characterised by shallow stream depths and low to medium water velocities, occurring at relatively low elevations (20-80 m AHD) in tributaries and the upper Mary River. Substrates were predominantly sand-gravel with very little coarse material (Table 4). Group 2 samples were subject to the most variable discharge conditions of the four sample groups identified, as indicated by the CV of mean daily discharge (816\%, Table 4). These samples were associated with surface waters of low ionic concentration and low TP concentrations (Table 4).

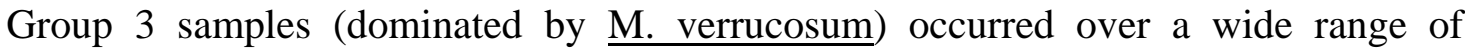
environmental conditions (Table 4) throughout the entire elevation range surveyed (0-160 m AHD) and were subjected to extremes of water velocity and discharge (Table 4). Median daily discharges were the highest amongst the four sample groups because group 3 samples were often collected from sites in the lower Mary River catchment, typically within the main channel (see Fig. 1). Substrates were generally coarser than for group 1 
and group 2 samples. Mean TP concentration of group 3 samples was approximately twice that of sample groups 1, 2 and 4 but mean TKN concentrations were comparable to groups 2 and 4 (Table 4). Group 3 samples were collected from streams with a wide range of ionic concentrations (as shown by conductivity) and pH conditions (Table 4).

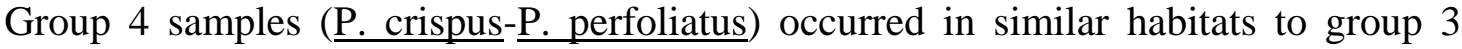
samples but were more often found at higher elevations in lower water velocities (Table 4). Maximum total daily discharge for group 4 samples was relatively low but the median total daily discharge was relatively large (Table 4). The mean number of zero flow days was also relatively low. Group 4 samples occurred in surface waters of low to high ionic concentration (Table 4).

\section{$\underline{3.3 \text { Sample ordination and relationships with environmental variables }}$}

Relationships between the four sample groups and environmental variables were further explored by ordination and correlation analyses (Fig. 3a-d). Macrophyte taxa and environmental variables that were significantly correlated with sample position in ordination space were consistent with taxa and environmental variables distinguishing UPGMA-defined sample groups (Tables 3 and 4, Fig. 3a-d). Elevation ( $r=0.595)$, distance to mouth $(r=0.580)$ and maximum daily discharge $(r=0.510)$ were the variables most highly correlated with the position of samples in ordination space (Table 5). Elevation and distance to mouth produce a clear gradient within the ordination space along which group 1 samples (․․ variifolium-Nitella spp.) are separated from samples dominated by $\underline{\mathrm{V}}$. nana,

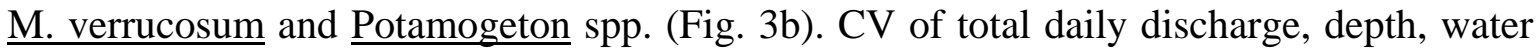
slope, TKN and $\mathrm{pH}$ also vary along the elevation gradient. Sample groups 2-4 are arrayed 
over a more complex gradient of water velocity and discharge descriptors on axis 2 and substrate particle size (sand versus gravel) and riparian cover on axis 3 (Fig. 3c-d).

\section{Discussion}

This study has examined submersed macrophyte assemblage structure in the context of environmental heterogeneity and assessed the applicability of a general conceptual model of aquatic macrophyte growth in streams (Riis and Biggs 2001). Multivariate analysis revealed four distinct submersed macrophyte assemblages in the Mary River catchment that were structured by two major environmental gradients. The first gradient, representing discharge intensity, discharge variability and total Kjeldahl nitrogen concentration, separated group 1 samples from the remaining sample groups. The second gradient representing substrate composition, discharge intensity, riparian canopy cover and total phosphorus concentration, separated groups 2-4. The environmental gradients structuring submersed macrophytes assemblages in the Mary River are in general agreement with the conceptual model of Riis and Biggs (2001). Both environmental gradients are constrained by geomorphology at the catchment as well as reach scale, particularly site elevation. Elevation is often cited as an important factor influencing the structure of macrophyte assemblages (Suren, 1996; Suren and Ormerod, 1998; Ferreira and Moreira, 1999). In the Mary River catchment, elevation was correlated with meso- and microscale habitat variables (discharge measures, water quality, depth, substrate composition, water velocity; Table 1) that are more direct influences on macrophyte growth than elevation itself (e.g. Chambers et al., 1991; Suren, 1996; Statzner et al., 1988). Pronounced spatial variation in meso- and micro-scale habitat characteristics occurred over a relatively narrow elevation gradient $(160 \mathrm{~m})$ compared with the variation across elevation gradients reported 
elsewhere (i.e. 750 m - Holmes et al., 1998; 3650 m - Suren and Ormerod, 1998). Discharge variations over the elevation gradient surveyed probably account for much of the environmental heterogeneity encountered at the meso- and micro-habitat scales in the Mary River catchment (see Table 4; Poff and Ward, 1989; Pusey et al., 1993; Mackay, Arthington and Kennard, unpublished data).

Macrophyte groups 1 and 3 were both dominated by amphibious species of Myriophyllum but appear at opposite ends of the hydraulic disturbance gradient. Both

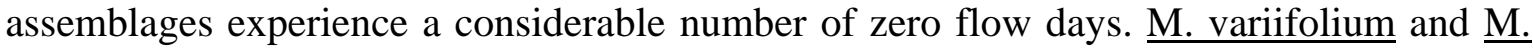
verrucosum are both tolerant of fluctuating water levels, particularly where exposure may occur, through traits such as heterophylly (Brock, 1991; Orchard, 1985). Falling water

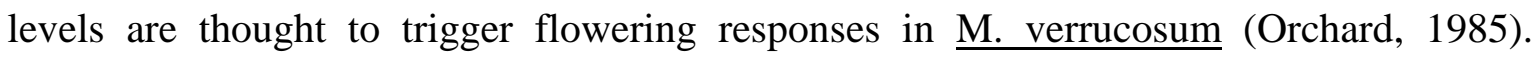
Samples dominated by $\underline{\mathrm{M}}$. variifolium were associated with discharges of relatively low magnitude and variability, low water velocities and coarse substrates dominated by gravel and bedrock. Tolerance of $\underline{\mathrm{M}}$. variifolium to high flows has not been reported but this species is usually found in still to slow flowing water (Orchard, 1985). At the other

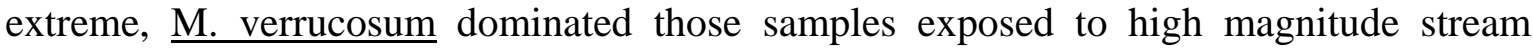
discharges, high water velocities and coarse substrates composed of gravels and cobbles. Both $\underline{M}$. variifolium and $\underline{M}$. verrucosum possess pinnate submerged leaves which may reduce drag in flowing water (Willby et al., 2000; see also Sand-Jensen 2003). However, M. variifolium has larger leaves (11-20 mm long, 11-23 mm wide) and greater stem diameter (up to $5 \mathrm{~mm}$ ) than $\underline{\mathrm{M}}$. verrucosum (leaves 6-12 $\mathrm{mm}$ long, 5-12 $\mathrm{mm}$ wide; stem diameter 1-1.5 mm; Orchard, 1985). Reduced surface area (i.e. smaller leaf area) and increased stem flexibility (i.e. reduced stem thickness) may allow $\underline{M}$. verrucosum to

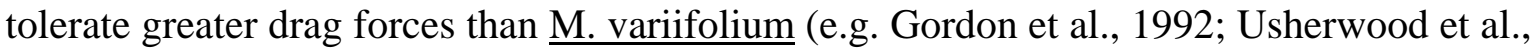


1997; Suren et al., 2000), which may explain the presence of the former species at high discharge sites.

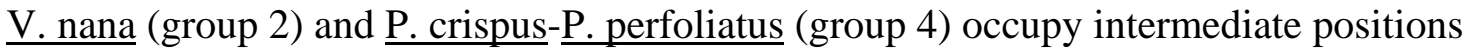
on the disturbance axis relative to $\underline{\mathrm{M}}$. variifolium and $\underline{\mathrm{M}}$. verrucosum. These taxa can be considered obligate aquatics (Kadono, 1984; Brock and Casanova, 1997). V. nana occurred on sandy substrates at low-medium water velocities and should therefore be exposed to less intense hydraulic disturbance than $\underline{\mathrm{M} \text {. verrucosum. }} \underline{\text { P. crispus-P. perfoliatus (group 4) }}$ were associated with similar water velocity and substrate conditions as $\underline{\mathrm{V}}$. nana, but were more often associated with stream discharges of lower magnitude than $\underline{V}$. nana (as indicated by maximum and minimum discharges and percentiles). We therefore assign $\underline{\mathrm{V}}$. $\underline{\text { nana }}$ to a higher position on the disturbance axis relative to $\underline{\mathrm{P} \text {. crispus-P. perfoliatus. }}$

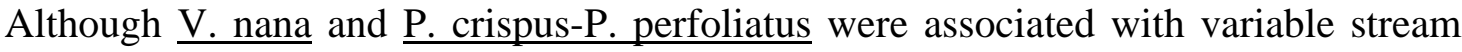
discharges they experienced relatively few days of zero flow. These species are not considered tolerant of repeated desiccation or exposure (Kadono, 1984; Preston, 1995; Preston and Croft, 1997; Blanch et al., 1999) but may survive in water several centimetres deep (Sainty and Jacobs, 1981; Preston and Croft, 1997). Myriophyllum spp. would therefore appear to have competitive advantages in habitats subject to periodic exposure.

The placement of submersed macrophyte taxa within the conceptual model of Riis and Biggs (2001) relative to resource availability is less straightforward since this axis

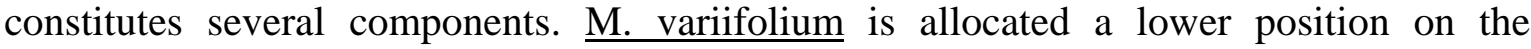
resource axis than the remaining taxa by virtue of its association with surface waters of low TKN and TP concentrations and low light environments (i.e. higher riparian canopy

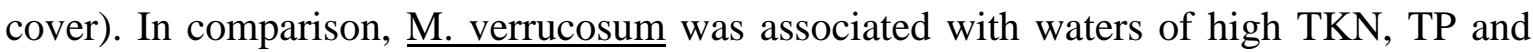
alkalinity (but low to intermediate light availability), suggesting that this species should be placed on the extreme of the resource axis. $\underline{V}$. nana was associated with low TKN 
concentrations, intermediate TP concentrations, low alkalinity and low riparian cover (high light availability). $\underline{\text { P. crispus-P. perfoliatus were associated with waters of low TP, high }}$ TKN, intermediate to low alkalinity and low riparian canopy cover. We therefore place these taxa in an intermediate position relative to $\underline{\mathrm{M}}$. variifolium and $\underline{\mathrm{M}}$. verrucosum on the resource supply axis. $\underline{P}$. crispus and $\underline{P}$. perfoliatus are often associated with mesotrophic and eutrophic waters or waters of high alkalinity (Spence and Maberley, 1985; Preston and Croft, 1997). The association of $\underline{P \text {. crispus }} \underline{P \text {. perfoliatus }}$ with surface waters of intermediate to low alkalinity is only relative to the ordination space, and does not imply an absolute requirement for waters of low alkalinity.

Implications of this study

In Australia, a commitment to Ecologically Sustainable Development of water resources and provision of environmental flows (Commonwealth of Australia, 1990; ARMCANZ and ANZECC, 1996) has prompted interest in establishing quantitative links between ecologically relevant hydrological descriptors and stream biota (Whittington, 2000). This study has shown that distinct submersed macrophyte assemblages are recognisable based on a small subset of taxa and that these assemblages can be associated with distinctive physical conditions in the Mary River catchment. It has also shown that the effects of hydrological and hydraulic parameters on submersed macrophytes cannot be considered in isolation from the effects of variations in resource availability, notably nutrients and light (Carr et al., 1997). The conceptual model for submersed macrophytes of the Mary River catchment includes both sets of variables and can be used to develop testable hypotheses predicting directions of change in assemblage structure for given changes in disturbance regimes and resource availability, as suggested by Riis and Biggs 
(2001). Such models and predictions could have application in developing methods for the use of aquatic macrophytes as stream bioassessment tools in Australia, particularly in defining the reference condition for aquatic macrophytes (Ferreira and Moreira, 1999), and evaluating changes in macrophyte assemblage structure in relation to riparian vegetation loss, water quality impairment and alterations to stream flow regimes, and their mitigation.

\section{Acknowledgements}

Data presented in this paper were collected as part of Land and Water Resources Research and Development Corporation (LWRRDC) Project No. GRU-10. We thank Celia Thompson and Darren Renouf for assistance with field work. Garry Werren (James Cook University), Thorsten Mosisch (Australian Water Quality Unit, SA Water) and two anonymous referees kindly reviewed drafts of the manuscript. Discharge data and funding for water quality analyses were provided by the Queensland Department of Natural Resources. This paper represents a contribution to the Cooperative Research Centres for Freshwater Ecology and Tropical Rainforest Ecology and Management.

\section{References}

American Public Health Association, 1995. Standard Methods for Analysis of Water and Wastewater, 19th edition. American Public Health Association, Water Works Association and Water Environment Federation, Washington.

ARMCANZ and ANZECC, 1996. National Principles for the Provision of Water for

Ecosystems. Sustainable Land and Water Resources Management Committee Subcommittee on Water Resources Occasional Paper SWR No. 3. 
Belbin, L., 1995. PATN: Pattern Analysis Package (Technical Reference). CSIRO Division of Wildlife and Ecology, Australia.

Biggs, B.J.F., 1996. Hydraulic habitat of plants in streams. Reg. Rivers: Res. Manage. 12, 131-144.

Blanch S.J., Ganf G.G. and Walker, K.F., 1999. Tolerance of riverine plants to flooding and exposure indicated by water regime. Reg. Rivers: Res. Manage. 15, 43-62.

Bridges, E.M., Ross, D.J., Thompson, C.H., 1990. Soils of the Mary River alluvia near Gympie, Queensland. CSIRO Division of Soils Divisional Report No. 109.

Brock, M.A., 1991. Mechanisms for maintaining persistent populations of Myriophyllum variifolium J. Hooker in a fluctuating shallow Australian lake. Aquat. Bot. 39, 211-219.

Brock, M.A., Cassanova, M.T., 1997. Plant life at the edge of the wetlands: ecological responses to wetting and drying patterns. In: Klomp, N., Lunt, I. (Eds.), Frontiers in Ecology: Building the Links. Elsevier Science, Oxford, pp. 181-192.

Bunn, S.E., Davies, P.M., Kellaway, D.M., Prosser, I.P., 1998. Influence of invasive macrophytes on channel morphology and hydrology in an open tropical lowland stream, and potential control by riparian shading. Freshwat. Biol. 39, 171-178.

Carr, G.M., Chambers, P.A., 1998. Macrophyte growth and sediment phosphorus and nitrogen in a Canadian prairie river. Freshwat. Biol. 39, 525-536.

Carr, G.M., Duthie, H.C., Taylor, W.D., 1997. Models of aquatic plant productivity: a review of the factors that influence growth. Aquat. Bot. 59, 195-215.

Casanova, M.T., 1994. Vegetative and reproductive responses of charophytes to waterlevel fluctuations in permanent and temporary wetlands in Australia. Aust. J. Mar. Freshwat. Res. 45, 1409-1419.

Chambers, P.A., Prepas, E.E., Hamilton, H.R., Bothwell, M.L., 1991. Current velocity and its effect on aquatic macrophytes in flowing water. Ecol. Applications 1, 249-257. 
Clarke, K.R., Warwick, R.M., 1994. Change in marine communities: an approach to statistical analysis and interpretation. Natural Environment Research Council, UK.

Commonwealth of Australia, 1990. Ecologically Sustainable Development. Commonwealth Discussion Paper. Australian Government Publishing Service Canberra.

Demars, B.O.L., Harper, D.M., 1998. The aquatic macrophytes of an English lowland river system: assessing response to nutrient enrichment. Hydrobiologia 384, 75-88.

Department of Primary Industries, 1993. The Condition of River Catchments in Queensland. Department of Primary Industries, Brisbane.

Farmer, A.M., Adams, M.S., 1989. A consideration of the problems of scale in the study of the ecology of aquatic macrophytes. Aquat. Bot. 33, 177-189.

Ferreira, M.T., Moreira, I.S., 1999. River plants from an Iberian basin and environmental factors influencing their distribution. Hydrobiologia 415, 101-107

Finlayson, B.L. McMahon, T.A., 1988. Australia v the world: a comparative analysis of streamflow characteristics. In: Warner, R.F. (Ed.), Fluvial Geomorphology of Australia. Academic Press, Sydney, pp. 17-40.

French, T.D., Chambers, P.A., 1996. Habitat partitioning in riverine macrophyte communities. Freshwat. Biol. 36, 509-520.

French, T.D., Chambers, P.A., 1997. Reducing flows in the Nechako River (British Columbia, Canada): potential response of the macrophyte community. Can. J. Fish. Aquat. Sci. 54, 2247-2254.

Gauch Jr, H.G., 1982. Multivariate Analysis in Community Ecology. Cambridge University Press, Cambridge.

Gordon, N.D., McMahon, T.A., Finlayson, B.L., 1992. Stream Hydrology: An Introduction for Ecologists. John Wiley and Sons, Chichester. 
Hart, D.D., Finelli, C.M., 1999. Physical-biological coupling in streams: the pervasive effects of flow on benthic organisms. Ann. Rev. Ecol. Syst. 30, 363-395.

Hill, N.M., Keddy, P.A., Wisheu, I.C., 1998. A hydrological model for predicting the effects of dams on shoreline vegetation of lakes and reservoirs. Environ. Manage. 22, 723-736.

Holmes, N.T.H., Boon, P.J., Rowell, T.A., 1998. A revised classification system for British rivers based on their aquatic plant communities. Aquatic Conser. Marine Freshwat. Ecosys. 8, 555-578.

Hughes, J.M.R., 1990. Lotic vegetation dynamics following disturbance along the Swan and Apsley Rivers, Tasmania, Australia. J. Biogeogr. 17, 291-306.

Jacobs, S.W.L., Frank, K.A., 1997. Notes on Vallisneria (Hydrocharitaceae) in Australia, with descriptions of two new species. Telopea 7, 111-118.

Johnson, D.P., 1997. State of the Rivers: Mary River and major tributaries. An ecological and physical assessment of the condition of streams in the Mary River catchment. Department of Natural Resources Resource Sciences Centre, Queensland.

Kadono, Y., 1984. Comparative ecology of Japanese Potamogeton: an extensive survey with special reference to growth form and life cycle. Jap. J. Ecol. 34, 161-172.

Keddy, P.A., 1992. Assembly and response rules: two goals for predictive community ecology. J. Veg. Sci. 3, 157-164.

King, S.A., Buckney, R.T., 2000. Urbanization and exotic plants in northern Sydney streams. Austral Ecology 25, 455-461.

Lemmon, P.E., 1956. A spherical densiometer for estimating forest overstorey density. Forest Sci. 2, 314-320.

Litav, M., Agami, M., 1976. Relationship between water pollution and the flora of two coastal rivers of Israel. Aquat. Bot. 2, 23-41. 
Mitchell, D.S., Rogers, K.H., 1985. Seasonality/aseasonality of aquatic macrophytes in southern hemisphere inland waters. Hydrobiologia 125, 137-150.

Muotka, T., Virtanen, R., 1995. The stream as a habitat templet for bryophytes: species’ distributions along gradients in disturbance and substratum heterogeneity. Freshwat. Biol. 33, 141-160.

Orchard, A.E., 1985. Myriophyllum (Haloragaceae) in Australasia. II. The Australian species. Brunonia 8, 173-291.

Palmer, M.A., Poff, N.L., 1997. The influence of environmental heterogeneity on patterns and processes in streams. J. N. Am. Benthol. Soc. 16, 169-173.

Poff, N.L., Ward, J.V., 1989. Implications of streamflow variability and predictability for lotic community structure: a regional analysis of streamflow patterns. Can. J. Fish. Aquat. Sci. 46, 1805-1818.

Preston, C.D., 1995. Pondweeds of Great Britain and Ireland. BSBI Handbook No. 8. Botanical Society of London.

Preston, C.D., Croft, J.M., 1997. Aquatic Plants in Britain and Ireland. Harley Books, Essex, England.

Puckridge, J.T., Sheldon, F., Walker, K.F., Boulton, A.J., 1998. Flow variability and the ecology of large rivers. Mar. Freshwater Res. 49, 55-72.

Pusey, B.J., Arthington, A.H., Read, M.G., 1993. Spatial and temporal variation in fish assemblage structure in the Mary River, south-eastern Queensland: the influence of habitat structure. Environ. Biol. Fishes 37, 355-380.

Queensland Department of Environment and Heritage, 1995. Water Quality Sampling Manual. Second Edition.

Rea, N., Ganf, G.G., 1994. How emergent plants experience water regime in a Mediterranean-type wetland. Aquat. Bot. 49, 117-136. 
Riis, T., Biggs, B.J.F., 2001. Distribution of macrophytes in New Zealand streams and lakes in relation to disturbance frequency and resource supply - a synthesis and conceptual model. New Zeal. J. Mar. Freshwat. Res. 35, 255-267.

Riis, T., Sand-Jensen, K., Vestergaard, O., 2000. Plant communities in lowland Danish streams: species composition and environmental factors. Aquat. Bot. 66, 255-272.

Royle, R.N., King, R.J., 1991. Aquatic macrophytes in Lake Liddell, New South Wales: biomass, nitrogen and phosphorus status, and changing distribution from 1981 to 1987. Aquat. Bot. 41, 281-298.

Sainty, G. R., Jacobs, S.W.L., 1981. Waterplants of New South Wales. Water Resources Commission of New South Wales.

Sainty, G.R., Jacobs, S.W.L., 1994. Waterplants in Australia, 3rd edition. Sainty and Associates, Darlinghurst.

Sand-Jensen, K., 2003. Drag and reconfiguration of freshwater macrophytes. Freshwat. Biol. 48, 271-283.

Sand-Jensen, K., Jeppesen, E., Nielsen, K.; Van der Bijl, L., Hjermind, L., Nielsen, L.W., Iversen, T.M., 1989. Growth of macrophytes and ecosystem consequences in a lowland Danish stream. Freshwat. Biol. 22, 15-32.

Schütz, W., 1995. Vegetation of running waters in southwestern Germany - pristine conditions and human impact. Acta bot. Gallica 142, 571-584.

Spence, D.H.N., Maberly, S.C., 1985. Occurrence and ecological importance of $\mathrm{HCO}_{3}{ }^{-}$use among aquatic higher plants. In: Lucas, W.J., Berry, J.A. (Eds.), Inorganic Carbon Uptake by Aquatic Photosynthetic Organisms. The American Society of Plant Physiologists, pp. 125-143.

Stanley, T. D. and Ross, E.M., 1983. Flora of South-Eastern Queensland, Volume 1. Queensland Department of Primary Industries, Brisbane. 
Stanley, T. D. and Ross, E.M., 1986. Flora of South-Eastern Queensland, Volume 2. Queensland Department of Primary Industries, Brisbane.

Stanley, T. D. and Ross, E.M., 1989. Flora of South-Eastern Queensland, Volume 3. Queensland Department of Primary Industries, Brisbane.

Statzner, B., Gore, J.A., Resh, V.H., 1988. Hydraulic stream ecology: observed patterns and potential applications. J. Nth. Am. Benthol. Soc. 7, 307-360.

SunWater, 2001. Water storage summary. http://www.sunwater.com.au/current storage_info.shtml. ResourceNet, Department Natural Resources and Mines, Queensland. Last updated 7 September 2001.

Suren, A.M., 1996. Bryophyte distribution patterns in relation to macro-, meso-, and micro-scale variables in South Island, New Zealand streams. New Zeal. J. Mar. Freshwat. Res. 30, 501-523.

Suren, A.M., Ormerod, S.J., 1998. Aquatic bryophytes in Himalayan streams: testing a distribution model in a highly heterogeneous environment. Freshwat. Biol. 40, 697716.

Suren, A.M., Smart, G.M., Smith, R.A., Brown, S.L.R., 2000. Drag coefficients of stream bryophytes: experimental determinations and ecological significance. Freshwat. Biol. 45, 309-317.

Usherwood, J.R., Ennos, A.R., Ball, D.J., 1997. Mechanical and anatomical adaptations in terrestrial and aquatic buttercups to their respective environments. J. Exp. Bot. 48, 1469-1475.

Ward, J., Talbot, J., 1984. Distribution of aquatic macrophytes in Lake Alexandrina, New Zealand. New Zeal. J. Mar. Freshwat. Res. 18, 211-220. 
Whittington, J., 2000. Development of Relationships Between Flow Regime and River Health. Cooperative Research Centre for Freshwater Ecology Technical Report No. 6/2000. University of Canberra, Canberra, Australia.

Willby, N.J., Abernathy, V.J., Demars, B.O.L., 2000. Attribute-based classification of European hydrophytes and its relationship to habitat utilization. Freshwat. Biol. 43, 4374.

Zar, J.H., 1996. Biostatistical Analysis, $3^{\text {rd }}$ edition. Prentice-Hall, New Jersey. 
Table 1

Spearman correlations for macroscale catchment descriptors (upstream catchment area, distance to river mouth, elevation) and meso- and micro-scale environmental variables. For clarity only significant correlations are shown $(\mathrm{p}<0.01)$. Range and median values for significant correlations also shown.

NS = not significant. The number of samples is 112

\begin{tabular}{|c|c|c|c|c|c|}
\hline Variable & $\begin{array}{r}\text { Upstream } \\
\text { Catchment Area } \\
\end{array}$ & $\begin{array}{r}\text { Distance to } \\
\text { Mouth } \\
\end{array}$ & Elevation & Range & Median \\
\hline $\begin{array}{l}\text { Catchment Descriptors } \\
\text { Upstream catchment area }\left(\mathrm{km}^{2}\right) \\
\text { Distance to mouth }(\mathrm{km}) \\
\text { Elevation }(\mathrm{m})\end{array}$ & $\begin{array}{r}1 \\
0.938 \\
-0.919 \\
\end{array}$ & $\begin{array}{r}1 \\
0.935 \\
\end{array}$ & 1 & $\begin{array}{r}26-4851 \\
10-211 \\
0-160 \\
\end{array}$ & $\begin{array}{r}176 \\
34 \\
80 \\
\end{array}$ \\
\hline $\begin{array}{l}\text { Discharge Descriptors } \\
\text { Max. total daily discharge }\left(\mathrm{m}^{3} \mathrm{~s}^{-1}\right) \\
10^{\text {th }} \text { percentile }\left(\mathrm{m}^{3} \mathrm{~s}^{-1}\right) \\
90^{\text {th }} \text { percentile }\left(\mathrm{m}^{3} \mathrm{~s}^{-1}\right) \\
\text { Median total daily discharge }\left(\mathrm{m}^{3} \mathrm{~s}^{-1}\right) \\
\text { CV of total daily discharge }(\%) \\
\text { Number of zero flow days }\end{array}$ & $\begin{array}{r}0.839 \\
0.879 \\
\mathrm{~ns} \\
0.726 \\
-0.299 \\
\mathrm{~ns} \\
\end{array}$ & $\begin{array}{r}-0.762 \\
-0.797 \\
\mathrm{~ns} \\
-0.591 \\
0.299 \\
-0.243 \\
\end{array}$ & $\begin{array}{r}-0.810 \\
-0.818 \\
\mathrm{~ns} \\
-0.688 \\
0.302 \\
\mathrm{~ns} \\
\end{array}$ & $\begin{array}{r}194-93165 \\
3.4-2573.8 \\
0-43.5 \\
0.1-245.6 \\
78-1314 \\
0-512 \\
\end{array}$ & $\begin{array}{r}4022 \\
35.4 \\
0.3 \\
2.9 \\
629 \\
44 \\
\end{array}$ \\
\hline $\begin{array}{l}\text { Physical Habitat } \\
\text { Width (m) } \\
\text { Water Velocity }\left(\mathrm{m} \mathrm{s}^{-1}\right) \\
\text { Riparian Cover }(\%) \\
\text { Gravel (\%) } \\
\text { Cobble (\%) } \\
\text { Rock (\%) }\end{array}$ & $\begin{array}{r}\mathrm{ns} \\
0.311 \\
-0.638 \\
0.410 \\
-0.384 \\
-0.519 \\
\end{array}$ & $\begin{array}{r}\mathrm{ns} \\
-0.243 \\
0.407 \\
-0.501 \\
0.399 \\
0.589 \\
\end{array}$ & $\begin{array}{r}\mathrm{ns} \\
-0.307 \\
0.516 \\
-0.501 \\
0.434 \\
0.579 \\
\end{array}$ & $\begin{array}{r}0.8-40.1 \\
0-0.8 \\
1-97 \\
0-82 \\
0-58 \\
0-47 \\
\end{array}$ & $\begin{array}{r}7.5 \\
0.05 \\
50 \\
38 \\
21 \\
0\end{array}$ \\
\hline $\begin{array}{l}\text { Water Quality } \\
\text { Conductivity }\left(\mu \mathrm{S} \mathrm{cm}^{-1}\right) \\
\text { Alkalinity }\left(\mathrm{mg} \mathrm{L}^{-1} \text { as } \mathrm{CaCO}_{3}\right) \\
\mathrm{pH} \\
\text { Water Temperature }\left({ }^{\circ} \mathrm{C}\right) \\
\text { Turbidity (NTU) } \\
\text { Total Kjeldahl Nitrogen }\left(\mathrm{mg} \mathrm{L}^{-1}\right) \\
\text { Total Phosphorus }\left(\mathrm{mg} \mathrm{L}^{-1}\right)\end{array}$ & $\begin{array}{l}0.449 \\
0.251 \\
0.327 \\
0.310 \\
0.416 \\
0.625 \\
0.530\end{array}$ & $\begin{array}{l}-0.629 \\
-0.411 \\
-0.418 \\
-0.218 \\
-0.485 \\
-0.644 \\
-0.539\end{array}$ & $\begin{array}{l}-0.538 \\
-0.296 \\
-0.372 \\
-0.258 \\
-0.474 \\
-0.602 \\
-0.553\end{array}$ & $\begin{array}{r}123-1903 \\
8.9-380.0 \\
6.38-8.70 \\
15-29 \\
0.4-25 \\
0.05-4.7 \\
0.001-0.520\end{array}$ & $\begin{array}{r}509 \\
115.0 \\
7.82 \\
19 \\
2.6 \\
0.2 \\
0.015\end{array}$ \\
\hline
\end{tabular}


Table 2

Submersed macrophyte taxa recorded from the Mary River catchment, May 1996-1997. Frequency of occurrence and mean taxon cover ( \pm standard error) were calculated from all 112 samples (four samples from sites in Wide Bay $\mathrm{Ck}$, which dried up for the final two surveys, were excluded from these calculations)

\begin{tabular}{lrrr}
\hline Taxon & $\begin{array}{r}\text { Frequency of } \\
\text { occurrence in } \\
\text { samples (\%) }\end{array}$ & $\begin{array}{r}\text { Mean cover } \\
\text { per quadrat } \\
(\%)\end{array}$ & $\begin{array}{r}\text { Cover } \\
\text { range (\%) }\end{array}$ \\
\hline Myriophyllum verrucosum Lindley & 33.9 & $6.0 \pm 1.2$ & $0-57.7$ \\
Vallisneria nana R. Br. & 30.4 & $6.8 \pm 1.3$ & $0-50.0$ \\
Potamogeton crispus L. & 29.5 & $2.2 \pm 0.5$ & $0-30.0$ \\
Myriophyllum variifolium J. Hooker & 12.5 & $3.1 \pm 0.9$ & $0-54.4$ \\
Hydrilla verticillata L.f. Royle & 10.7 & $1.0 \pm 0.4$ & $0-30.0$ \\
Nitella spp. & 8.9 & $0.8 \pm 0.3$ & $0-23.1$ \\
Potamogeton perfoliatus L. & 7.1 & $1.9 \pm 0.9$ & $0-57.3$ \\
Chara spp. & 6.3 & $0.7 \pm 0.4$ & $0-30.0$ \\
Potamogeton tricarinatus F. Muell. \& A. Benn. & 5.4 & $0.6 \pm 0.3$ & $0-25.0$ \\
ex A. Benn. & & & \\
Najas tenuifolia R. Br. & 3.6 & $0.1 \pm 0.1$ & $0-5.7$ \\
Callitriche sp. & 3.5 & $0.5 \pm 0.3$ & $0-24.6$ \\
Ceratophyllum demersum L. & 2.7 & $0.2 \pm 0.1$ & $0-9.3$ \\
Potamogeton ochreatus Raoul & 0.9 & $0.01 \pm 0.01$ & $0-0.9$ \\
\hline
\end{tabular}


Table 3

Mean cover ( \pm standard error) of submersed macrophyte taxa occurring in sample groups defined by UPGMA classification of Mary River samples. Only taxa having significantly different cover (Kruskal-Wallis tests) between sample groups shown. For each taxon, the figure in brackets represents the percentage occurrence in samples in each UPGMA group

\begin{tabular}{lrrrrr}
\hline Taxon & $\begin{array}{r}\text { Group 1 } \\
(\mathrm{n}=13)\end{array}$ & $\begin{array}{r}\text { Group 2 } \\
(\mathrm{n}=17)\end{array}$ & $\begin{array}{r}\text { Group 3 } \\
(\mathrm{n}=32)\end{array}$ & $\begin{array}{r}\text { Group 4 } \\
(\mathrm{n}=15)\end{array}$ & p-value \\
\hline Nitella sp. & $5.6 \pm 2.0(69)$ & $0.7 \pm 0.7(6)$ & $0(0)$ & $0(0)$ & 0.000 \\
M. variifolium & $26.1 \pm 3.5(100)$ & $0(0)$ & $0 \pm 0.05(3)$ & $0(0)$ & 0.000 \\
$\underline{\text { V. nana }}$ & $0(0)$ & $30.0 \pm 3.7(100)$ & $6.6 \pm 2.0(41)$ & $2.6 \pm 1.4(27)$ & 0.000 \\
$\underline{\text { M. verrucosum }}$ & $3.0 \pm 1.3(46)$ & $0.4 \pm 0.2(18)$ & $19.5 \pm 2.8(91)$ & $0(0)$ & 0.000 \\
$\underline{\text { P. tricarinatus }}$ & $0(0)$ & $0(0)$ & $2 \pm 1(41)$ & $0(0)$ & 0.029 \\
$\underline{\text { P. crispus }}$ & $1.1 \pm 1.0(15)$ & $0.9 \pm 0.6(24)$ & $2.0 \pm 0.6(41)$ & $10.3 \pm 2.3(93)$ & 0.000 \\
$\underline{\text { P. perfoliatus }}$ & $0(0)$ & $1 \pm 0.5(12)$ & $0(0)$ & $14 \pm 6(40)$ & 0.000 \\
\hline
\end{tabular}


Table 4

Mean values ( \pm standard error) for environmental variables determined by Kruskal-Wallis tests to be significantly different between UPGMA-defined macrophyte sample groups

\begin{tabular}{|c|c|c|c|c|c|}
\hline Environmental Variable & Group 1 & Group 2 & Group 3 & Group 4 & p-value \\
\hline \multicolumn{6}{|l|}{ Catchment Descriptors } \\
\hline Elevation (AHD, m) & $126 \pm 6$ & $49 \pm 6$ & $43 \pm 7$ & $85 \pm 11$ & 0.000 \\
\hline Upstream catchment area $\left(\mathrm{km}^{2}\right)$ & $79 \pm 9$ & $730 \pm 146$ & $1870 \pm 353$ & $349 \pm 93$ & 0.000 \\
\hline Distance to mouth (km) & $254 \pm 7$ & $182 \pm 15$ & $162 \pm 9$ & $225 \pm 13$ & 0.000 \\
\hline \multicolumn{6}{|l|}{ Discharge Descriptors } \\
\hline Max. discharge $\left(\mathrm{m}^{3} \mathrm{~d}^{-1}\right)$ & $1.1 \times 10^{6} \pm 3.3 \times 10^{5}$ & $2.5 \times 10^{7} \pm 5.9 \times 10^{6}$ & $4.1 \times 10^{7} \pm 7.0 \times 10^{6}$ & $6.4 \times 10^{6} \pm 3.3 \times 10^{6}$ & 0.000 \\
\hline $90^{\text {th }}$ Percentile $\left(\mathrm{m}^{3} \mathrm{~d}^{-1}\right)$ & $15418 \pm 3850$ & $90347 \pm 16203$ & $727569 \pm 177679$ & $61269 \pm 13217$ & 0.000 \\
\hline CV of total daily discharge (\%) & $452.4 \pm 0.3$ & $815.6 \pm 0.7$ & $594.1 \pm 0.3$ & $670.2 \pm 1.4$ & 0.000 \\
\hline Med. discharge $\left(\mathrm{m}^{3} \mathrm{~d}^{-1}\right)$ & $1408 \pm 210$ & $5494 \pm 544$ & $65722 \pm 16095$ & $13727 \pm 4701$ & 0.001 \\
\hline $10^{\text {th }}$ Percentile $\left(\mathrm{m}^{3} \mathrm{~d}^{-1}\right)$ & $140 \pm 53$ & $280 \pm 99$ & $13310 \pm 3275$ & $4600 \pm 1849$ & 0.019 \\
\hline Number of zero flow days & $193 \pm 37$ & $116 \pm 23$ & $155 \pm 33$ & $60 \pm 24$ & 0.041 \\
\hline \multicolumn{6}{|l|}{ Physical Habitat } \\
\hline \% Bedrock & $1 \pm 1$ & $0 \pm 0$ & $0 \pm 0$ & $0 \pm 0$ & 0.000 \\
\hline Water slope (\%) & $0.01 \pm 0$ & $0.18 \pm 0.07$ & $0.60 \pm 0.14$ & $0.72 \pm 0.23$ & 0.000 \\
\hline \% Cobble & $22 \pm 4$ & $5 \pm 4$ & $21 \pm 3$ & $24 \pm 5$ & 0.000 \\
\hline Depth (cm) & $62 \pm 6$ & $38 \pm 6$ & $32 \pm 4$ & $37 \pm 7$ & 0.003 \\
\hline \% Rock & $2 \pm 1$ & $0 \pm 0$ & $5 \pm 2$ & $5 \pm 2$ & 0.005 \\
\hline Water velocity $\left(\mathrm{m} \mathrm{s}^{-1}\right)$ & $0.01 \pm 0.01$ & $0.08 \pm 0.03$ & $0.24 \pm 0.05$ & $0.12 \pm 0.05$ & 0.014 \\
\hline \% Sand & $9 \pm 5$ & $34 \pm 9$ & $5 \pm 2$ & $15 \pm 6$ & 0.016 \\
\hline \% Gravel & $39 \pm 3$ & $33 \pm 8$ & $50 \pm 3$ & $33 \pm 5$ & 0.029 \\
\hline \multicolumn{6}{|l|}{ Water Quality } \\
\hline Total Phosphorus $\left(\mu \mathrm{g} \mathrm{L}^{-1}\right)$ & $17 \pm 10$ & $18 \pm 2$ & $32 \pm 5$ & $13 \pm 2$ & 0.000 \\
\hline Total Kjeldahl Nitrogen $\left(\mathrm{mg} \mathrm{L}^{-1}\right)$ & $0.14 \pm 0.02$ & $0.30 \pm 0.03$ & $0.31 \pm 0.02$ & $0.26 \pm 0.04$ & 0.000 \\
\hline $\mathrm{pH}$ & $7.81 \pm 0.11$ & $8.20 \pm 0.14$ & $8.27 \pm 0.07$ & $8.16 \pm 0.05$ & 0.029 \\
\hline
\end{tabular}


Table 5

Principal Axis Correlation coefficients for submersed macrophyte taxa and environmental parameters significantly correlated with SSHMDS ordination of Mary River samples. Significance determined by Monte-Carlo randomisation. Significance $*_{0.05}^{*} \mathrm{p}<0.01$; ** $\mathrm{p}<0.01$

\begin{tabular}{|c|c|c|c|}
\hline Taxa & $\mathbf{r}$ & Environmental Variables & $\mathbf{r}$ \\
\hline V. nana & $0.913 * *$ & Catchment Descriptors & \\
\hline P. crispus & $0.849 * *$ & Elevation & $0.595 * *$ \\
\hline M. variifolium & $0.837 * *$ & Distance to mouth & $0.580 * *$ \\
\hline$\overline{\text { M. verrucosum }}$ & $0.803 * *$ & Subcatchment area & $0.450 * *$ \\
\hline Nitella spp. & $0.694 * *$ & Discharge Descriptors & \\
\hline P. perfoliatus & $0.506 * *$ & Maximum daily discharge & $0.510 * *$ \\
\hline P. tricarinatus & $0.504 * *$ & CV of daily discharge & $0.457 * *$ \\
\hline \multirow[t]{17}{*}{ H. verticillata } & $0.354 *$ & $\begin{array}{l}90^{\text {th }} \text { Percentile of total daily } \\
\text { discharge }\end{array}$ & $0.369 * *$ \\
\hline & & Median daily discharge & $0.334 *$ \\
\hline & & Physical habitat & \\
\hline & & Riparian Cover & $0.498 * *$ \\
\hline & & \% Sand & $0.479 * *$ \\
\hline & & \% Gravel & $0.409 * *$ \\
\hline & & \% Bedrock & $0.404 * *$ \\
\hline & & Water velocity & $0.351 *$ \\
\hline & & Depth & $0.328 *$ \\
\hline & & Water slope & $0.323 *$ \\
\hline & & Water Quality & \\
\hline & & Total Hardness & $0.503 * *$ \\
\hline & & Conductivity & $0.491 * *$ \\
\hline & & Alkalinity & $0.482 * *$ \\
\hline & & & $0.468 * *$ \\
\hline & & Total Kjeldahl Nitrogen & $0.342 *$ \\
\hline & & Total Phosphorus & $0.318 *$ \\
\hline
\end{tabular}


Figure Captions

Figure 1. Location of the Mary River catchment and study sites (numbered 1-53). Note that site numbers are not indicative of the total number of sites included in this study. The main channel of the Mary River shown in bold.

Figure 2. Hydrographs for representative Mary River sites. The period of study is indicated by dashed vertical lines.

Figure 3. SSHMDS ordination of Mary River samples based on $\log (\underline{\mathrm{x}}+1)$ transformed species cover (common species only). Stress $=0.137,3$ dimensions (ratio regression). Variance explained by axes 2 and $3=67.3 \%$. (a) Distribution of samples and UPGMA groups in ordination space. (b) Direction of significant correlations for submersed macrophyte taxa with the ordination. (c) Direction of significant correlations for physical habitat variables (including site position in catchment) with the ordination. (d) Direction of significant correlations for water quality variables with the ordination. Vectors labelled with abbreviations: DMOU, Distance to Mouth; ELEV, Elevation; AREA, Subcatchment area; DEP, Depth; BEDR, \% Bedrock; RCOV, \% Riparian cover; GRAV, \% Gravel; MED, Median total daily discharge; 90TH, 90th percent of total daily discharge; SLOPE, Water slope; MAX, Maximum total daily discharge; VEL, Water velocity; CV, CV of total daily discharge; SAND, \% Sand. 


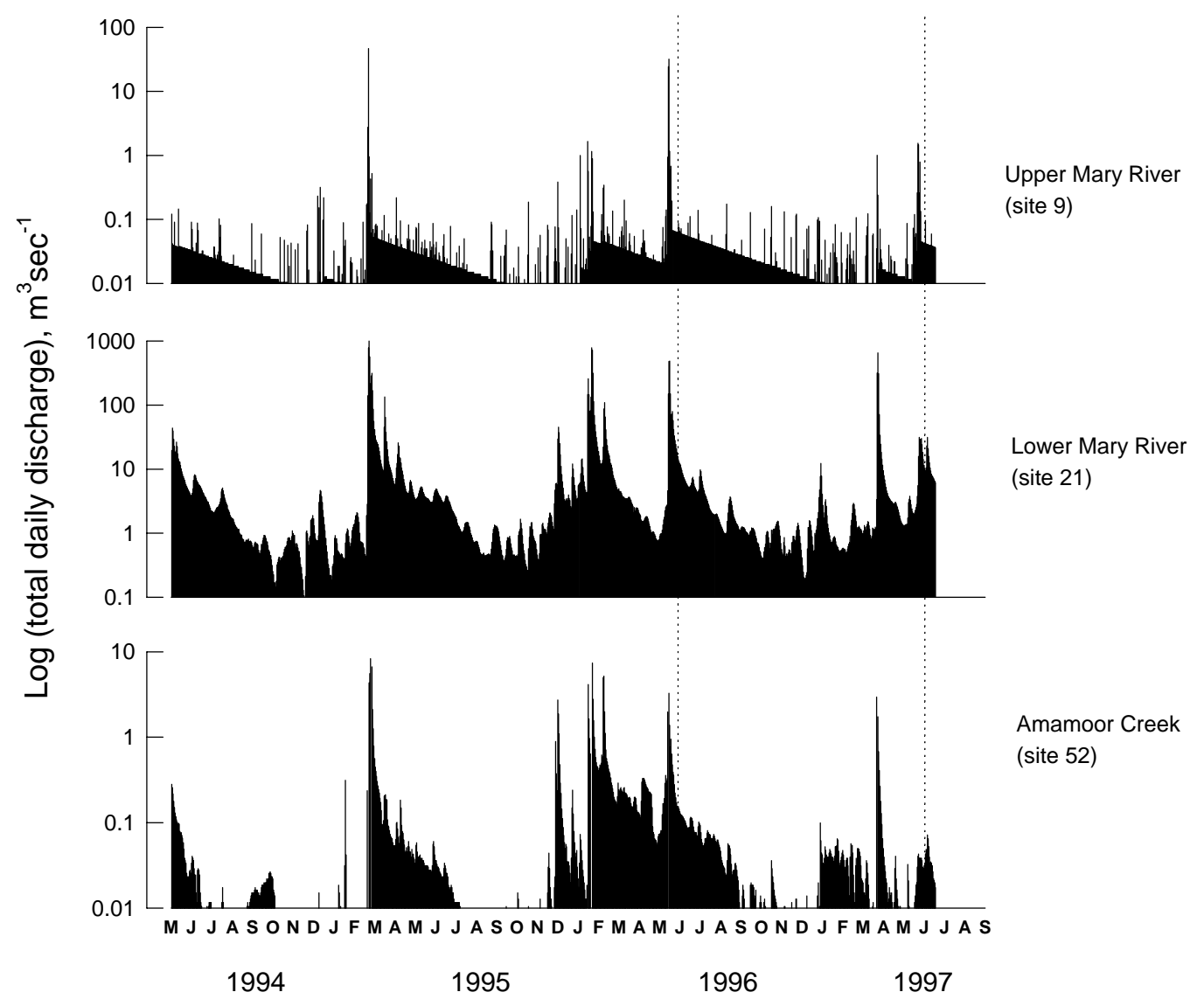




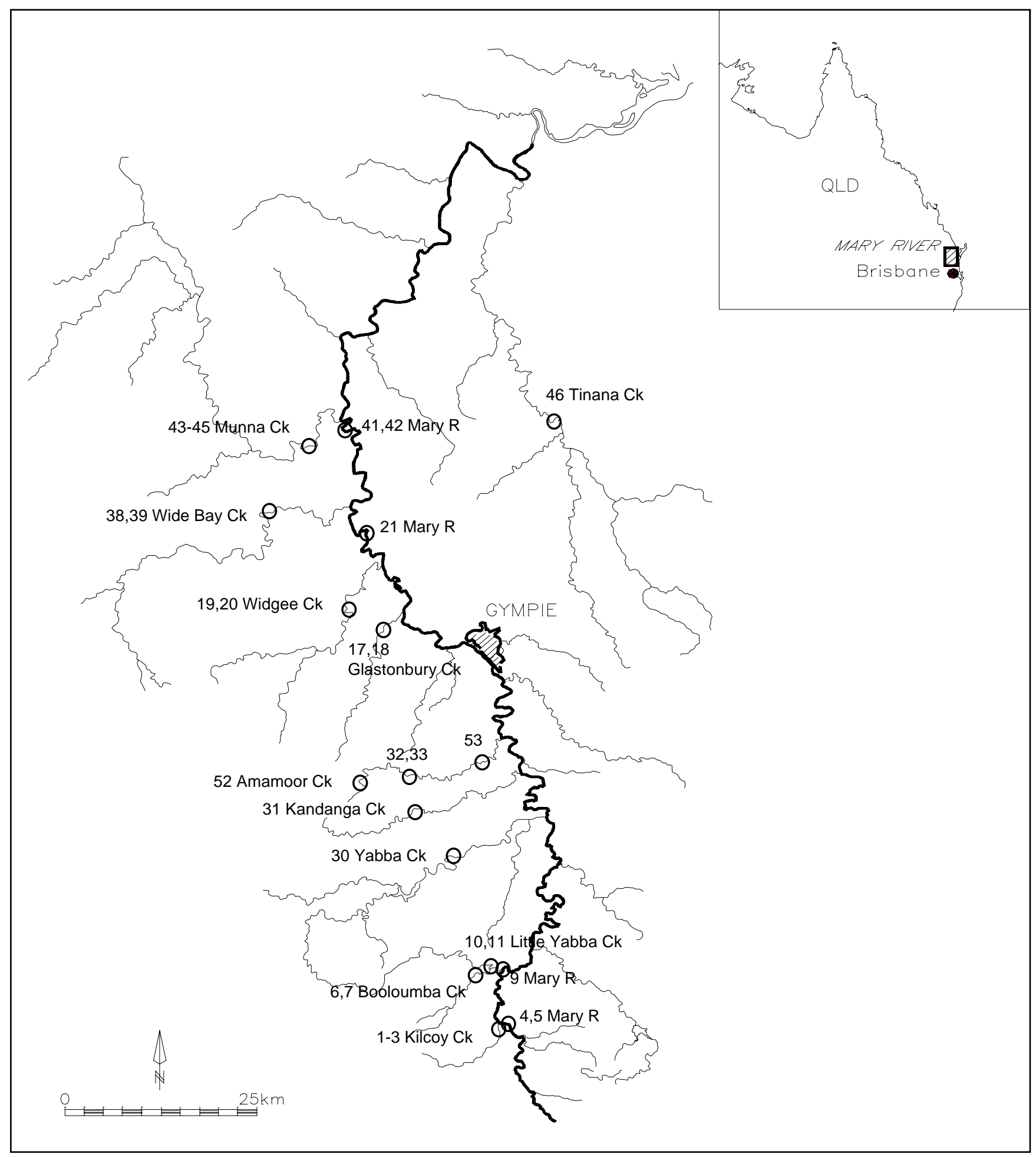



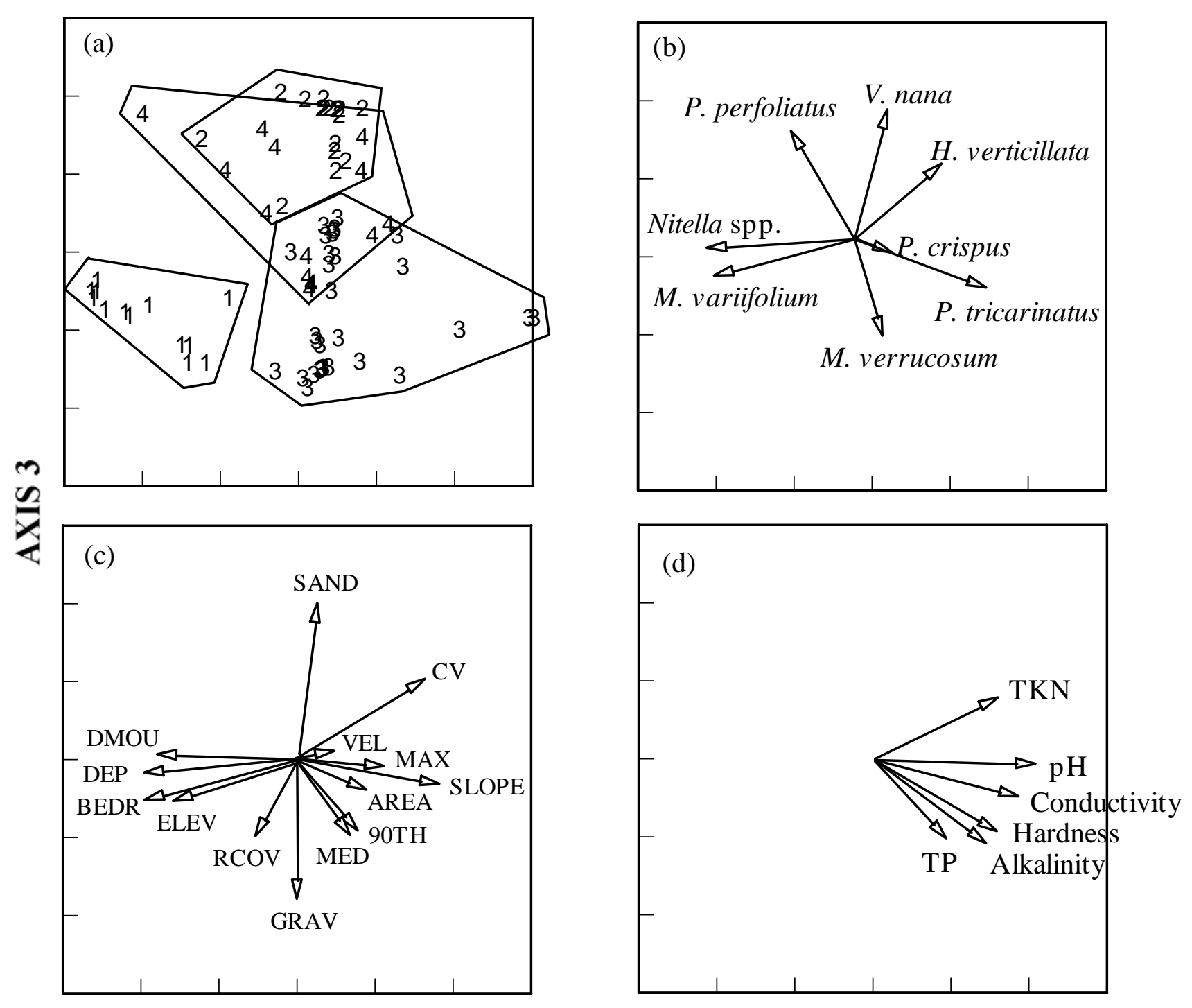

AXIS 2 